\title{
Resección de tumores cardíacos: experiencia en el Hospital Privado Universitario de Córdoba
}

\author{
Dominella FG. ${ }^{1}$, Longo S. ${ }^{1}$ \\ 1 Hospital Privado Universitario de Córdoba, Córdoba, Argentina.
}

Introducción: Las masas cardíacas constituyen un verdadero desafío debido a que, por su rareza, requieren un alto nivel de sospecha para ser diagnosticadas. Sin embargo, debido a la utilización cada vez mayor de métodos de diagnostico por imágenes y a la sofisticaciones de los mismos, su hallazgo resulta cada vez más frecuente. Entre los métodos de diagnóstico para las mismas encontramos al Ecógrafo transesofágico, que permite no solo diagnostico si no monitores perioperatorio de las mismas.

Métodos: Se trata de un estudio observacional descriptivo. Presentamos nuestra experiencia en resección de tumores cardíacos: 25 pacientes, 11 mixomas, 5 fibroeslastomas, 3 sarcomas y 5 tumores renales con invasión cardíaca y 1 trombo organizado.

Destacamos la utilidad de la ecocardiografía transesofágica como monitor, hoy imprescindible en cirugía cardíaca.

Resultados: La ecografía trans esofágica nos permitió confirmar la localización del tumor y su completa resección. Así mismo como anestesiólogos y formando parte activa en el equipo quirúrgico pudimos documentar la ausencia de defectos residuales, perforaciones o incompetenciade las válvulas cardíacas; evaluar la función ventricular y la volemia post circulación extracorpórea, obtener información no conocida previamente y realizar así un diagnóstico precoz de complicaciones.

Conclusión: El ETE es un monitor imprescindible para el manejo perioperatorio de las masas cardiacas, permitiendo al anestesiólogo tomar un rol preponderante durante la cirugía, ya que es capaz de guiar la conducta quirúrgica y de detectar las complicaciones derivadas de la misma.

https://doi.org/10.25237/congresoclasa2019.50 